Os chefes de departamento não foram ouvidos, ou seja, não foram envolvidos no processo de mudança.

\title{
7. Críticas
}

A crítica tem enderêço certo. Seja qual fôr o processo de mudança, uma ou mais pessoas estarão sendo alvo de críticas. Afinal, por que foi preciso que um assessor modificasse uma seção de contrôle de frequiência? Por que não o próprio chefe? Esta é uma pergunta tradicional em mudanças.

\section{Flexibilidade}

Um processo de mudança deve ser suficientemente flexível para que algumas distorções sejam eliminadas. Nem sempre uma mudança organizacional alcança sucesso dentro de sua forma original.

$\mathrm{O}$ que o leitor encontrou acima foi apenas um receituário para a efetivação de mudanças na organização. Judson busca muito mais. Por isso indicamos a obra para os estudantes de administração pública ou de emprêsas, para os empresários e, também, para os assessôres que estão a todo instante às voltas com mudanças organizacionais.

\section{LUÍS CÉSAR GONÇALVES DE ARAÛJO}

Bureaucracy and Innovation - Por Victor A. Thompson. Edição da Universidade de Alabama, 1969, 167 páginas.

O assunto dêste livro, a relação entre estruturas administrativas e a capacidade de inovar é de interêsse especial para os administradores e para os observadores do processo de desenvolvimento sócio-econômico.

Embora exemplos sejam retirados predominantemente das instituições públicas e privadas dos Estados Unidos da América, a análise dos problemas enfrentados pelas organizações grandes 
e formais (large-scale formal organizations) é sumamente relevante às sociedades onde a industrialização está produzindo mudanças sociais, as quais necessitam de abordagens inovadoras à administração.

Em Bureaucracy and Innovation, Thompson propõe duas questões básicas para as sociedades modernas e para aquelas em processo de modernização onde as instituições tradicionais são repudiadas em favor do que J. K. Galbraith tem denominado a "corporação madura". " Essas questões são as seguintes:

1. São as instituições administrativas herdadas de um período de escassez de informação adequadas às necessidades de um periodo de abundância de informação?

2. A vida organizacional irá conduzir no futuro à inteligência, à criatividade e à atualização do indivíduo através do trabalho (self-actualization)?

Tanto em relação às previsões otimistas quanto pessimistas exemplos abundantes fazem evidente a ausência de respostas claras a estas questões. O valor de Bureaucracy and Innovation se encontra na análise sugestiva das possibilidades e tendências das instituições burocráticas. Em vez de ter o caráter de uma receita, o livro é uma exposição importante de idéias sôbre a adaptação da administração às necessidades modernas.

$\mathrm{O}$ assunto, por sua natureza, não se presta fàcilmente a uma abordagem empírica. Porém, "para remediar deficiências metodológicas na pesquisa sôbre as organizações, o autor recomenda a aplicação dos métodos acadêmicos e a teoria das ciências sociais ao problema da inovação burocrática". Segundo Thompson, "um programa interdisciplinar de pesquisa com um modêlo unificador" é necessário para mostrar:

1. que a produção e a inovação variam inversamente, e

2. que os métodos estruturados da burocracia monocrática operam contra a criatividade.

1 E interessante notar que as características da cultura industrial listadas no apêndice do livro de THOMPSON são aplicáveis à mature corporation, uma organização grande e formal controlada por uma tecno-estrutura de profissionais. Veja: O Nôvo Estado Industrial, por J. K. GalbRaIth. 
A organização burocrática é um sistema social. Por isso, para estudar a inovação como um possível output dêsse sistema, as condições que conduzem ao comportamento inovador devem ser comparadas com aquelas fornecidas pela burocracia. Nesta comparação Bureaucracy and Innovation é mais sèriamente deficiente.

A discussão da criatividade é geral e as conclusões de Thompson não são sistemáticas. Seu sumário das condições empíricas da criatividade (p. 11) é superficial..

A discussão da teoria das decisões é complicada desnecessàriamente pela erudição confusa de Thompson. Além disso, suas conclusões não são muito relevadoras. Por exemplo, que o processo decisório nas organizações pode ser mais inovador "numa situação permissiva e indulgente" que numa situação onde "o comportamento programado ou determinado (impede a flexibilidade)" parece óbvio.

De qualquer maneira, o reconhecimento de Thompson da necessidade de transcender "a racionalidade econômica", como o critério das decisões, e a sua sugestão de que "a liberdade é necessária para explorar a incerteza" realçam a importância da criação de opções viáveis à tirania e à futilidade da vida moderna prevista por escritores como George Orwell e Aldous Huxley.

Thompson argüe que "a economia e a coerência devem estar presentes (nas organizações modernas), mas não devem dominar". .. "não são pròpriamente as metas finais desta ou qualquer outra sociedade". ${ }^{2}$

Assim como J. K. Galbraith mudou o foco básico da análise econômica do homem econômico para o homem organizacional, Thompson muda o foco da teoria das organizações, da produção e contrôle managerial para as implicações inovadoras da cultura moderna.

Ambos, Thompson e Galbraith, buscam a função entrepreneurial nas organizações modernas. Os dois autores encontram na

2 Thompson, pejorativamente, nomeia tal dominação da economia, da coerência e da eficiência como managerialism. 
tendência para o profissionalismo ${ }^{3}$ uma alternativa à rigidez da burocracia monocrática.

Thompson, como Galbraith, descreve a administração moderna em têrmos de motivações humanas que tem mudado bastante, e o progresso inovador dentro das organizações modernas em têrmos de liberdade individual, não apenas nos têrmos tradicionais das barreiras sócio-econômicos e dos processos estruturais da burocracia.

O neo-taylorismo que tem reaparecido com o advento da tecnologia moderna (computor technology) se baseia, segundo Thompson, na crença ingênua de que a ciência pode resolver os problemas sociais. Isso tem levado alguns teoristas à conclusão errada de que o managerialism é universal.

Bureaucracy and Innovation ilustra amplamente as razões pelas: quais o know-how administrativo dos norte-americanos não mais pode ser entendido como uma panacéia para os problemas dos países subdesenvolvidos. Valeria a pena traduzir o livro nem. se fôsse apenas por esta razão.

RICHARD S. HILLMAN

Liderança e Organização - Abordagem à Ciência do Comportamento - Por Robert Tannembaun, Irwing R. Weschler e Fred: Massarik. Tradução do original em inglês, por Auriphebo B. Simões. São Paulo, Editôra Atlas S.A., 1970, 516 páginas.

O livro de Tannembaun, Weschler e Massarik publicado em 1961 nos Estados Unidos e agora traduzido para o português, constitui-se de uma coleção dos artigos estampados pelos membros do Human Relations Research Group (HRRG), do Instituto de Relações Industriais e Escola de Pós-Graduação em Adminis-

s Thompson disse que "o profissionalismo se baseia no conceito de investimento no 'capital humano', em vez do conceito do trabalho como mercadoria". Semelhantemente, a tecno-estrutura de Galbraith se baseia no que THompson nomeia a "nova elite do poder" (p. 55). 